\title{
ARTIGO
}

CO https://doi.org/10.22481/praxisedu.v15i36.5935

\section{CORPORATE CULTURE OF EDUCATIONAL ORGANIZATION AS A FACTOR OF INFLUENCING THE SOCIAL HEALTH OF THE RUSSIAN STUDENT YOUTH}

\author{
CULTURA CORPORATIVA DE LA ORGANIZACIÓN EDUCATIVA COMO FACTOR \\ DE INFLUENCIA EN LA SALUD SOCIAL DE LA JUVENTUD ESTUDIANTIL RUSA
}

\section{CULTURA CORPORATIVA DA ORGANIZAÇÃO EDUCACIONAL COMO FATOR DE INFLUÊNCIA NA SAÚDE SOCIAL DOS JOVENS ESTUDANTES RUSSOS}

Karina S. Chikaeva

Kuban State Agrarian University named after I.T. Trubilin - Russia

Nataliia $V$. Gorbunova

Vernadsky Crimean Federal University (CUH), Republic of Crimea - Russia

Vladimir A. Vishnevskij

Vernadsky Crimean Federal University (CUH), Republic of Crimea - Russia

Nataliia Iu. Fominykh

Plekhanov Russian University of Economics, Moscow - Russia

Iuliia V. Gluzman

Vernadsky Crimean Federal University (CUH), Republic of Crimea - Russia

Olga I. Shkuropy

Kuban State Technological University AIMT (branch) of KubSTU - Russia

Valentina I. Odintsova

Don State Technical University, Rostov-on-Don - Russia

\begin{abstract}
Resumo: No artigo, a cultura corporativa de uma organização educacional é considerada um fator de influência na saúde social dos jovens estudantes russos. A base teórica e metodológica do estudo consiste nas disposições conceituais da teoria sociológica, revelando dois conceitos básicos: "cultura corporativa de uma organização educacional" e "saúde social dos jovens estudantes russos". Os autores destacam as principais funções da cultura corporativa; dar uma análise sociológica do conceito de "saúde social" da juventude. A atitude em relação à saúde no nível da cultura corporativa de uma organização educacional é um sistema de padrões corporativos em relação à saúde social e seu valor em geral e à política social dessa organização no campo da saúde. $\mathrm{O}$ artigo revela orientações orientadas para a personalidade e a função da cultura das relações corporativas em termos de seu impacto na saúde social dos jovens.
\end{abstract}


Palavras-chave: Cultura corporativa; Organização educacional; Jovens estudantes russos; Saúde social; Ambiente educacional.

Abstract: In the article, the corporate culture of an educational organization is considered as a factor of influencing the social health of Russian student youth. The theoretical and methodological base of the study consists of the conceptual provisions of sociological theory, revealing two basic concepts: "corporate culture of an educational organization" and "social health of Russian student youth". The authors highlight the main functions of corporate culture; give a sociological analysis of the concept of "social health" of youth. The attitude to health at the level of corporate culture of an educational organization is a system of corporate standards in relation to social health and its value in general and the social policy of this organization in the field of health. The article reveals personality- and functionally-oriented directions of the culture of corporate relations in terms of their impact on the social health of young people.

Keywords: Corporate culture; Educational organization; Russian student youth; Social health; Educational environment.

Resumen: En el artículo, la cultura corporativa de una organización educativa se considera un factor que influye en la salud social de los jóvenes estudiantes rusos. La base teórica y metodológica del estudio consiste en las disposiciones conceptuales de la teoría sociológica, que revela dos conceptos básicos: "cultura corporativa de una organización educativa" y "salud social de los jóvenes estudiantes rusos". Los autores destacan las principales funciones de la cultura corporativa; Dar un análisis sociológico del concepto de "salud social" de la juventud. La actitud hacia la salud a nivel de cultura corporativa de una organización educativa es un sistema de estándares corporativos en relación con la salud social y su valor en general y la política social de esta organización en el campo de la salud. El artículo revela direcciones orientadas a la personalidad y la funcionalidad de la cultura de las relaciones corporativas en términos de su impacto en la salud social de los jóvenes.

Palabras clave: Cultura corporativa; Organización educativa; Juventud estudiantil rusa; Salud social; Ambiente educativo.

\section{Introduction}

All life processes of any organization occur within the framework of corporate culture. The needs of modern students are very broad and diverse. Young people spend a significant part of their time in an educational institution and wish to receive from the educational activity something more than just knowledge and skills. The corporate culture of the educational organization is called upon to solve this problem. The special role of the corporate culture of the educational organization is manifested in the fact that it provides spiritual, social development and realization of creative potential of students as well as teachers and leaders. A variety of events within the corporate culture of the educational organization aimed at 
developing student youth - training (academic and practical), sporting events, leisure time together, visits to cultural institutions, hobby groups, innovation, the pursuit of a healthy lifestyle, etc. - contribute to the development and stabilization of the organization itself and the formation of personality. One of the key and most important areas of influence of corporate culture is the adaptation of young people and the formation of their social health.

Corporate culture along with the professional competence of a teacher in a multicultural education is an immanent property of any higher educational institution as an organization (Vishnevsky, 2016; Vishnevsky, 2018). Integrity, covering everything that is connected with the human world, and the latent presence in many individual manifestations of the universal, makes culture an indispensable qualitative characteristic, without which it is impossible to understand and describe, perhaps, not a single phenomenon of human interaction (Enygin \& Fominykh et al, 2018).

Young people as a socio-demographic group, which acts as a carrier of significant intellectual and creative potential, as well as a reserve for replenishing reproductive and labor resources, must have significant reserves of physical, mental and social health (Gafiatulina, 2015; Gafiatulina et al, 2018).

The high quality of training of student youth, the ability of this social group to accumulate and transmit knowledge is largely due to the level of their social health, which is important for the successful social functioning of both young people themselves and society as a whole. Therefore, of particular importance in today's higher education system are the activities aimed at the formation of the social health of students, which, together with the professional level are the indicators of quality of highly qualified personnel training (Fominykh et al, 2018) determining the economic prosperity and social well-being of the state. A significant role in shaping the social health of Russian student youth, according to E.V. Tsikalyuk, plays the organizational culture of the university, "which through the declared, encouraged by the university goals, values, norms, accepted patterns of behavior and communication, relationships and activities affects the process of formation of students' social health, determining its level" (Tsikalyuk, 2012).

The problem of organizational university culture influence on social health of student youth has not been made the object of sociological analysis yet, but it is contextually and indirectly touched upon in the various areas of scientific knowledge. Analysis of the scientific works, directly or indirectly related to the issues of organizational culture research and social health, allows us to select a number of areas on the problem of interest to us. In particular: 
- Organizational culture as a complex multidimensional phenomenon that combines unique characteristics of the organization (N.V. Volkova, V.A. Spivak and others);

- Study of the personal characteristics of students in the organizational culture of a higher educational institution (A.V. Pogodina, V.M. Yuryev, etc.);

- Research on the study of various aspects of social health (LV Bulygin, IV Zhuravlev, NM Rimashevskaya, et al.).

The influence possibilities of the corporate culture of the educational organization, the transformation of the corporate culture itself with the goal of comprehensive development of the individual and (as a result) strengthening the organization are still being explored and reflected by sociologists.

\section{Materials and Methods}

As part of the analysis of the nodal vectors of modernization of Russian education in the scientific literature, little attention is paid to the issue of considering the corporate culture of an educational organization as one of the key factors affecting the social health of modern students. Health, as a phenomenon of social nature, cannot be interpreted from the standpoint of purely biomedical and clinical bio psychological views (Chikaeva et al, 2018).

The current situation related to the state of social health of Russian student youth in the modern educational space requires the inclusion of interdisciplinary knowledge (Wang et al, 2018).

Medicine, hygiene and health care system are important, but not the only sectors responsible for the formation, preservation and promotion of young people's health. The scientific sociological discourse states that the institution of education in general and higher education in particular becomes the main factor involved in the formation of the personality of a young individual as a whole (Fominykh et al, 2016), and the formation of his social health, in particular. However, the impact of corporate culture as an important part of the educational space of an educational organization on the social health of students still remains little discovered neither does the system of factors determining this influence.

The theoretical and methodological base of the study consists of the conceptual provisions of sociological theory, revealing two basic concepts: "corporate culture of an educational organization" and "social health of Russian students". Using the concept of "corporate culture" in social science is primarily a problem of development of sociological 
methodology. The analyzed phenomenon has not yet been adapted to the conceptual apparatus of sociology, despite the fact that there are efforts to "get close" and comprehend through culture.

In solving the problems of this study, such general scientific methods as analysis, synthesis, comparison were applied; the method of social interviewing of student youth was used as well as a functional approach that is traditional for the social and humanitarian field of scientific knowledge, and allows to highlight the functions of the corporate culture of the educational organization and to identify signs of social health of Russian student youth.

\section{Results}

The concept of "corporate culture" goes back to the generic concept of "culture" and is an integral element of a particular culture with its values, traditions, the language of concepts acting as norms, systems of relations and social mechanisms that lead the interaction of relations to a real result (Volkov, 2001).

Before talking about the corporate culture of a particular educational organization, it is necessary to determine the functions of this culture.

Those, according to the authors, are three:

1. An integrative-disintegrative function, which is designed to unite or share student youth on the basis of a sense of community, ownership, belonging to a single whole (people, nation, educational institution and so on) (Shakhbanova et al, 2018).

2. The educational function, providing in the process of secondary socialization of student youth familiarization with certain social and cultural values, making possible further cultural identification of a person (Shakbanova, Gafiatulina, et al, 2018).

3. Regulatory and managerial function that allows introducing a managerial, directing and regulatory component into corporate relations between employees and students of this educational organization (Chikaeva et al, 2018). At its core, this function, which implements in a certain way values, ideals, goals, norms, patterns of behavior through the creation of a system of preferences, prescriptions and prohibitions, reinforced by the action of sanctions.

On the one hand, "Culture is what determines the social aspect of the human person in terms of learned and acquired behavior. Culture is dynamic, as is the personality who has 
adopted the culture, and both of them (both personality and culture) change under the influence of circumstances and time" (Quinn, 2008). On the other hand, the organization's culture is defined as “... a historically determined set of living conditions, sociocultural and spiritual values, ideas, knowledge in the field of upbringing, enlightenment, education, science and art" (Kapto, 2005). Here, as we see, the essential side of corporate culture is spirituality and sociality.

From the point of view of the authors of this publication, the corporate culture of an educational organization is an element of its microenvironment, which has its own specifics of impact on the personality of student youth and their social health. As you know, the main function of the corporate culture of an educational organization in relation to young people is to transmit corporate norms, requirements, and sociocultural expectations. This determines one of the main parameters of the development of student youth in any educational organization, expressed in the system of its objectively significant and socially determined behavior, including in relation to social health.

According to our ideas, the influence of the corporate culture of an educational organization on the social health of students is determined by a number of circumstances.

Firstly, by defining the intragroup view of young people about an educational organization, and being an important source of stability and continuity, corporate culture can contribute to creating a sense of student confidence in the university as an organization and its position in it, as well as foster a sense of social security and trust (Shakhbanova et al, 2019).

Secondly, corporate culture of an educational organization reflects the level of satisfaction of students with their social status in the educational environment (Gafiatulina et al, 2018).

Thirdly, corporate culture of an educational organization stimulates the self-awareness and high responsibility of a student performing the tasks assigned to him. Recognizing and rewarding particularly outstanding student youth, the corporate culture of the educational organization identifies them as role models (certain patterns of behavior), thereby forming a special corporate spirit.

Fourthly, proclaiming the concern for maintaining physical, mental and social health of the individual, both within the educational organization for each employee and student, and in front of the society as a whole, corporate culture forms the value of a healthy personality for Russian society (Vaskov et al, 2018).

Consider the concept of "social health". 
This concept refers to the original category of "health."

In accordance with the Charter of the World Health Organization (WHO), health is interpreted as a state of complete physical, mental and social well-being, while "social wellbeing is a dynamic state of mind characterized by some mental harmony between the abilities, needs and opportunities that the environment presents and provides" (World Health Organization, 2008).

Depending on the accepted criteria of the typology of health, it is placed in the field of view of biologists and physicians (physical health), psychologists, psychiatrists and psychotherapists (mental health), demographers (public health or population health), ethnology (ethnos health), philosophers and specialists in the field of spiritual culture (spiritual health), sociologists and social workers (social health) (Gryshai et al, 2018).

The state of social health of Russian student youth is one of the most important indicators of the social well-being of Russian society, reflecting not only the current situation, but also the forecast for the future. In addition, understanding the social health of Russian youth is extremely important for the reason that this socio-demographic group "is required to adapt to a variety of situations, develop the most entrepreneurial models of social behavior based on the implementation of personal reserves" (Zhuravleva, 2009; Kashurina, 2007). According to L.I. Bulygina, social health of the young generation is associated with the influence of society as a whole on the personality of other people and depends on the place and role of each young person in interpersonal relationships, on the social health of society. It is a measure of social activity, ability to work, a form of active attitude towards the world. The social component of health is formed under the influence of close people, classmates at school, fellow students at university, work colleagues, etc., which reflects social connections, resources, interpersonal contacts, and a culture of interaction in a group and organization (Bulygina, 2009).

Social health is provided not only by physical and mental well-being, but also by the state of spiritual, moral and cultural relations (Ponomarev et al, 2019). The most important sign of the social health of Russian student youth, in our opinion, is its ability to actively and adequately perform its own socially acceptable functions in the educational space.

The following facts, for example, can evidence in favor of social health: despite subjective self-esteem, the personal qualities of students are ultimately recognized in comparison with other people according to established cultural standards, estimated by a specific educational community, because each student is not an isolated individual, but an element of the set of social and cultural relations. 
Social health of Russian student youth can be traced in such social phenomena as:

- Socio-cultural interaction in the educational organization, which is a factor in the external manifestation of the social health of youth (Karapetyan \& Kholmanskikh, 2015);

- Social norms enshrined in the corporate culture of a particular educational organization, reflecting the internal component of social well-being (Kovaleva et al, 2019).

- Socialization, in the process of which the formation of personal, spiritual principles of the social health of Russian youth occurs (Chikaeva et al, 2019).

Thus, social health is not a static state, but a dynamic one, and this state is largely determined by the social variable through the system of culture of corporate relations, into which student youth enter in the process of their interaction.

By creating its own system of rules, norms, various sanctions, requirements, guidelines, corporate culture can have a significant impact on the formation of a particular type of behavior, including in relation to health. As I.V. Zhuravleva, a domestic researcher in the field of studying attitudes towards health, indicates, “... the majority of behavior types important in terms of effects on health are caused by motives that are not directly related to health and are largely programmed into individual patterns and institutional life of communities. It turned out that health behavior, as a result of generally accepted everyday activities, does not require conscious motivation and special efforts. Thus, the behavior is more a consequence of the impact of culture and social structure, rather than personal motives and beliefs" (Zhuravleva, 2009). Models of behavior that directly depend on the conscious motivation of youth turn out to be less stable than models that are a natural result of the influence of socio-cultural norms and traditions of a particular educational organization. This is confirmed by the changes that have occurred in recent decades in different countries due to increased attention to youth health. For example, bans on smoking in public places, mass enthusiasm for jogging, and performing gymnastic exercises in public places have a greater impact on the social and cultural consciousness of the younger generation than any prevention program aimed at changing the individual behavior of young people (Gafiatulina et al, 2019).

In other words, the determination of such behavior is the result of the interaction of the individual with specific socio-cultural conditions of life. This explains the fact that in the same social conditions and corporate influence from the side of a specific educational 
organization, we are dealing with the phenomenon of deviant or going out from sociocultural norms behavior in the youth environment.

Given all of the above, it can be argued that social health can be considered as an indicator of the quality of the surrounding sociocultural environment and corporate culture of the educational organization in which students are socialized.

Since the corporate culture of the educational organization is part of the social environment, it also has a relatively independent meaning, because changes in the information space of corporate relations alter the system of motives, norms, value orientations, which may result in deviant behavior, including in relation to social health. Social health of student youth is the result of direct interaction of young people with the educational space through factors of successful or unsuccessful adaptation. In this regard, the problem of the sociocultural adaptation of student youth to the corporate culture of a particular educational organization is important.

Corporate culture changes the sociocultural environment of the educational organization and causing certain changes in the lifestyle of student youth. Thus, according to research by VA Medic and AM Osipova, "shifts in the sociocultural environment are manifested in the fact that the autonomy of young people, their independence in planning their own time budget, and the choice of social circle and types of leisure activities are relatively enhanced at the student age and in the student environment" (Medic \& Osipov, 2005). Corporate culture of the educational organization, introducing changes into the sociocultural environment, expresses itself in the transitioning some students during their studies in a certain educational organization to a new system of values, in which the priority is following the prestigious lifestyle. This style among Russian student youth as a whole combines the attributes of adulthood and at the same time focuses on youth exclusivity, the desire for independence and at the same time for adequate interaction with the educational community, which, within the framework of our publication, is an educational organization and its corporate relations.

Corporate culture of an educational organization can be aimed at the individual, i.e. to have a personality-oriented nature, aimed at self-actualization, self-development of the personality of student youth in the process of implementing educational activities; but it can also be functionally oriented, when the prevailing values are the execution of functionally defined algorithms for the implementation of educational activities in accordance with a certain model of sociocultural behavior.

In the case of a personality-oriented corporate culture of the educational organization, young people are satisfied with their own social health, motivated assessment of their own 
social well-being and behavior, as well as the impact of public opinion on the young person self-preserving behavior.

Under the dominance of a functionally oriented culture of corporate relations in the educational organization, the opposite picture is evident: health concern, motivated assessment of behavior associated with risk to social health.

We conducted an empirical study among students of the south of Russia, during which the following pattern was revealed: under a personality-oriented corporate culture, about 59\% of the students surveyed are satisfied with their social health and consider themselves to be healthy people; $14 \%$ of respondents are dissatisfied with their social health, but consider themselves to be practically healthy people; $27 \%$ of the surveyed student youth do not have a positive or negative opinion regarding their social health, but at the same time are more often satisfied with their health.

Students who pointed out the dominance of certain functionally defined behaviors at the university showed a different pattern during the survey: $34 \%$ of the respondents are not satisfied with their social health, but consider themselves to be practically healthy; $18 \%$ indicate satisfaction with social well-being at the university; do not consider themselves practically healthy, but find satisfaction with social well-being - 13\%; the rest did not give an intelligible answer.

It should be noted that the positive self-esteem of social health among students is combined with a higher satisfaction with relationships not only in interaction with other student groups, but is also noted in relations with the teaching staff of the educational organization. Moreover, there is an inverse relationship among students referring to social health problems; they often come across a critical assessment of the culture of relationships within the educational environment.

According to our ideas, the corporate culture of an educational organization, having a personality-oriented nature, presupposes social development of youth, by which we mean a certain integral process of qualitative changes in its essential characteristics, aimed at successful socialization and self-realization of a young personality.

Of particular importance for understanding the mechanisms of the influence of corporate culture of educational environment on the social health of young people are life skills and ability to live in a community acquired through the influence of corporate culture. By life skills, consistent with the definition of WHO, we mean the ability to adaptive and positive behavior that allows a young person to successfully and effectively cope with emerging 
difficulties and satisfy the whole spectrum of vital needs. In relation to social health, life skills are psychosocial and interpersonal communication skills in an educational organization that help young people to think positively and critically and creatively, communicate effectively and build healthy, harmonious relationships, empathize with other people, and organize their lives in a healthy and productive way, which ultimately is the main sign of social health.

The main function of corporate culture in relation to students as a social whole is to transfer the requirements, norms, social expectations of the educational organization staff as a special social group and microenvironment element (Gluzman et al, 2018), which has its own specifics of influencing the personality of a young person and his social health.

Corporate culture of an educational organization, influencing the social health of youth, contributes to the formation of a certain attitude of students to their health. Attitude to health is one of the foundations of a person's value system, a set of motives that connect a person with society and culture. Attitude to health can be considered at the macro level, i.e. at the level of society, and at the micro level - at the level of corporate culture of a particular social group, educational organization. We define "attitude to health at the level of corporate culture of an educational organization" as a system of existing opinions, established social norms existing at the university regarding health, and implemented in actions aimed at changing the state of social health at various levels of government.

The attitude to health at the level of corporate culture of an educational organization is, firstly, a system of corporate norms regarding social health and its value in general; secondly, the social policy of this organization in the field of health.

In our opinion, to assess the level of influence of corporate culture of an educational organization on the social health of students, it is advisable to evaluate corporate relations from the standpoint of the severity of risk factors. Such a classification, of course, is somewhat arbitrary, but, in our opinion, may look like this:

A high level of risk of corporate relations culture in relation to social health (the presence of strong negative group corporate pressure, the lack of an attitude to maintain a positive socio-psychological climate and a healthy lifestyle, the lack of a system of positive value orientations in relation to social health, the low awareness of educational institution staff on the issue of students' social well-being).

Low risk level (absence of negative pressure from the corporate culture of the educational organization, orientation towards maintaining a favorable socio-psychological climate and maintaining a healthy lifestyle, the presence of a system of positive value 
orientations in relation to social health, sufficient awareness of the educational organization about the students' social well-being).

Intermediate level of risk (the above factors are presented to a lesser extent than in the first classification).

\section{Discussion}

Corporate culture of an educational organization has a strong synthetic nature. Being a factor of influence on the social health of youth, this culture arises at the intersection of many types of cultures: professional, work culture, communication culture, culture of professional behavior, culture of conflict resolution, legal culture, political culture, ethical and aesthetic culture, communication culture, exchange culture, educational culture and others (Tsikalyuk, 2012).

The peculiarity of corporate culture, according to E.F. Vlasova, lies in the fact that it comes in the interaction of the spiritual and material culture. The corporation (regarded as a social community) unites not only employees, but also students who simultaneously "produce material (artifacts, their own products for sale) and spiritual values (corporate spirit, moral principles, loyalty, brands, ceremonies, rites of passage, etc.)". The development of corporate culture of an educational organization "occurs through the interaction of people who are united by the social community itself to fulfill its mission, achieve its goals, and carry out substantive activities." Everyone is "in continuous communication, regulated by values, norms, rules, language, traditions, customs, etc.” (Vlasova, 2010).

Culture in general, and corporate culture in particular, is, according to A.A. Oganova and I.G. Khangeldieva, "an integral system with its inherent certainty of value-hierarchical relationships" (Oganova \& Khangeldieva, 2004). However, corporate culture of any educational organization is not homogeneous, because it contains a certain range of subcultures: communicative-competent, professional-pedagogical, administrative-managerial, organizational, healthcare, etc. (Gorbunova \& Kalimullin, 2017).

Tereshchuk E.A. defines corporate culture of a university as a set of goals, values, norms, traditions shared by employees formed under the influence of internal and external factors, ensuring the uniqueness, self-preservation and self-development of the organization and the individual (Tereshchuk, 2006). 
By definition of V.A. Spivak, corporate culture is a system of material and spiritual values, manifestations, interacting with each other, inherent in this organization, reflecting its individuality and perception of oneself and others in the social and material environment, manifested in behavior, interaction, perception of oneself and the environment. This is a set of the most important provisions adopted by members of the organization and expressed in the values declared by the organization, giving people guidelines for their behavior and actions (Spivak, 2011), affecting their well-being.

According to V.V. Kasyanov, L.A. Minasyan et al., The substantial level of the corporate culture of the educational environment is the system of its values: certain behavior, activity, initiative, orientation towards a healthy lifestyle and the formation of social health (Kasyanov et al., 2018).

\section{Conclusion}

Thus, in general, the analysis of the scientific literature on the social health allows us to focus on the understanding it as a reflection of society's attitude to a person, which is implemented through a social communication and culture of interaction. In turn, corporate culture of an educational organization involves a certain level of relations, which cannot but affect the social health of the personality of a young man. Thus, corporate culture of an educational organization can be considered as one of the factors that have a direct impact on the social health of students.

The main sign of the social health of Russian student youth is their ability to actively and adequately perform their own socially acceptable functions in the educational space.

We believe that the study of corporate culture of educational organization`s impact on the social health of student youth is essential in application. It can help overcome dysfunctions and deviations in the corporate culture of interpersonal relations within the framework of higher professional education, and become the basis for improving the quality of corporate culture as a whole.

\section{REFERENCES}

1. Bulygina L.V. (2009). Social health of adolescents, Abstract ... Cand. Sociologic Sciences. Stavropol. 
2. Chikaeva K.S., Belikova N.Yu., Kasyanov V.V., Lyubetsky N.P., Zagirova E.M., Nagieva M.K., Remikhanova R.I. (2019). The Traditional Family: the Institutional Invariants of Development on the South of Russia. Dilemas contemporáneos: Educación, Política y Valores, 6(3), 49.

3. Chikaeva K.S., Scherbakova L.I., Karapetyan E.A., Latysheva A.T., Kosinov S.S., Zinchenko Ya.G., Samygin S.I. (2018). Social Health of Russian Youth: the Specifity of Social and Managerial Technologies of Formation. International Transaction Journal of Engineering, Management and Applied Sciences and Technologies, 9(6), 515-525.

4. Enygin D.V., Fominykh N.Y., Bubenchikova A.V., Inakiarregiorue J., Aubakirova R. (2018). To the definition of the notion "multicultural educational environment", Astra Salvensis, 1(11), 601-616.

5. Fominykh N., Barsova O., Zarudnaya M., Kolomiytseva N. (2016). Approaches to Prospective Economists Professional Foreign Language Training in Computer Orientated Language Learning Environment, N. Fominykh, O. Barsova, M. Zarudnaya, N. Kolomiytseva // International Journal of Environmental and Science Education, 11(18), 12067-12083.

6. Fominykh N., Zarudnaya M., Enygin D., Galakhov D., Epifanov D., Eferova A. (2018). Methodological Approaches to University Instructors Professional Foreign Languages Competence Development, The Journal of Social Sciences Research, 5, 375-381.

7. Gafiatulina N.K, Vorobyev G.A., Imgrunt S.I., Samygin S.I., Latysheva A.T.., Ermakova L.I., Kobysheva L.I. (2018). Social Health of Student Youth in South Russia: Analysis of the Perception of Socio-Cultural Risks. Modern Journal of Language Teaching Methods, 8(6), 32-41.

8. Gafiatulina N.Kh. (2015). Social health of students in the gender dimension, Bulletin of Perm State University, 17, 146-157.

9. Gafiatulina N.Kh., Makadei L.I., Gluzman I.V., Lozhechkina A.D., Volkova L.A., Bandurin A.P. (2019). Integration of Health-saving Technologies in the Process of Education and Professional Socialization of the Russian Student-age Population. International Journal of Applied Exercise Physiology, 8(2.1), 293-300.

10. Gluzman Yu.V., Yaraya T.A., Rokotyanskaya L.O. (2018). The development of inclusive higher education in the Crimean region: stages and prospects / in the book: The development of inclusion in higher education: a network approach Ser. "Library of the journal" Psychological Science and Education" Moscow, 55-60.

11. Gorbunova N.V., Kalimullin A.M. (2017). Simulation of the Process of Training the Future Primary School Teachers for Organizing Extracurricular Activities. // Elementary Education Online, 16(4), 1860-1872.

12. Gryshai V., Gafiatulina N., Kasyanov V., Velikodnaya I., Kosinov S., Lyubetsky N., Samygin S. (2018). Social Health of Youth in the Context of Migration Processes in Russia: Assessment of the Threat to National Security. Вісник Національної академії керівних кадрів культури і мистецтв, 2, 141-145.

13. Kapto A.S. (2005). Encyclopedia of the World. M., 297 p.

14. Karapetyan E.A., Kholmanskikh V.I. (2015). Opinion on family in a modern language environment and a globalizing culture, in the collection: Family in traditional and modern society: problems of adaptation. Collection of scientific papers on the materials of the International scientific-practical conference, 52-59.

15. Kashurina I.A. (2007). Deviant strategies of Russian youth / Thesis for the degree of Candidate of sociological sciences.

16. Kasyanov V.V., Minasyan L.A., Borodai V.A., Ponomarev I.E., Samygin P.S., Vorobyev G.A., Skvortsov D.V. (2018). Health Management and the Strategies to Meet 
a Healthy Society. International Transaction Journal of Engineering, Management and Applied Sciences and Technologies, 9(4), 357-368.

17. Kovaleva T.N., Maslova Yu.V., Kovalev N.A., Karapetyan E.A., Samygin S.I., Kaznacheeva O.K., Lyashenko N.V. (2019). Ecohumanistic Education in Russia and China as a Factor of Sustainable Development of Modern Civilization. Dilemas contemporáneos: Educación, Política y Valores, 6(3), 11.

18. Medic V.A., Osipov A.M. (2005). University students. M.

19. Oganov A.A., Khangeldieva I.G. (2004). Theory of Culture. M., 245 p.

20. Ponomarev I.E., Gafiatulina N.K., Zritineva E.I., Kasyanov V.V., Bahutashyili T.V., Ponomarev P.A. (2019). The Influence of Social Justice Crisis on Social Health and Spiritual security of Young Students (Case Study of the South of Russia). International Journal of Applied Exercise Physiology, 8(2.1), 250-257.

21. Quinn R.T. (2008). Beyond Rational Menagement. S.F.

22. Shakbanova M.M., Gafiatulina N.Kh., Samygin S.I., Chapurko T.M., Levaya N.A. Bineeva N.K. (2018). Youth of the South of Russia: Specifics of manifestation of ethnic identity (on the example of the Dagestan republic). Purusharta, 10(2), 111-119.

23. Shakhbanova M.M., Kasyanov V.V., Gafiatulina N.Kh., Gluzman I.V., Polivina M.A., Gnatyuk M.A., Ramazanov R.O. (2019). The Role of Trust in the Formation of Ethnic Tolerance and Social Health in the Modern Russian Society. Revista Inclusiones, 6(2), 296-305.

24. Spivak V.A. (2011). Corporate culture: theory and practice. SPB: Peter.

25. Tereshchuk E.A. (2006). Features of corporate culture in public service bodies: sociological analysis. Abstract of the Thesis for the degree of Candidate of Sociological Sciences. - Yekaterinburg.

26. Vaskov M., Rezvanov A., Kasyanov V., Samygin S., Gafiatulina N., Zagutin D., Scherbakova L. (2018). Value Orientations of Russian Youth in the System of Managing the Moral Security of Society, Herald National Academy of Managerial staff of culture and arts, 2, 134-140. http://heraldnamsca.in.ua/index.php/hnamsca/article/view/309.

27. Vishnevsky V.A. (2016). Profiography as a field of scientific knowledge and the current direction of the study of professions, Humanities (Yalta), 2 (34), 89-95.

28. Vishnevsky V.A. (2018). Key aspects of the formation of professional competence of a teacher in a multicultural education, In the book: Innovative approaches to solving the problems of modern society monograph. Penza, 26-33.

29. Vlasova E.F. (2010). Corporate culture as a factor in the social adaptation of new employees: abstract ... Cand. Sociologic Sciences. Yekaterinburg, 21 p.

30. Volkov Yu.G. (2001). Social culture, Sociology: a brief thematic dictionary, under the general. ed. Yu.G. Volkova. Rostov n / D., 187.

31. Wang S., Gorbunova N. V., Masalimova A. R., Birova J. et al. (2018). Formation of academic mobility of future foreign language teachers by means of media education technologies, Eurasia Journal of Mathematics, Science and Technology Education, 14 (3), 959-976.

32. World Health Organization. Commission on the Social Determinants of Health. Closing the gap in a generation. WHO, Geneva (2008).

33. Zhuravleva I.V. (2009). Attitude to the health of the individual and society. M. 


\section{SOBRE OS AUTORES:}

\section{Karina S. Chikaeva}

Doctor of historical sciences, associate professor, Department of sociology and cultural studies of FSBEI HE Federal State Budgetary Educational Institution of Higher Education «Kuban State Agrarian University named after I.T. Trubilin», Russia. Email: chikaevakarina@mail.ru (iD http://orcid.org/0000-0003-4396-104X

\section{Nataliia V. Gorbunova}

Doctor of Education, Professor, Head of Department, Of pedagogical mastery of primary school teachers and preschool teachers, V.I. Vernadsky Crimean Federal University (CUH), Republic of Crimea, Russia. E-mail: natalya-gor2008@yandex.ru

\section{(iD http://orcid.org/0000-0001-6102-2252}

\section{Vladimir A. Vishnevskij}

Ph.D. in Pedagogically science, associate Professor, Department of Pedagogics and Management of Educational Institutions, V.I. Vernadsky Crimean Federal University (CUH), Republic of Crimea, Russia. Email: vmwbox@gmail.com

(iD) http://orcid.org/0000-0002-2189-7203

\section{Nataliia Iu. Fominykh}

Doctor of Education, Professor, Humanitarian Training Center Foreign Languages Department\#1, Plekhanov Russian University of Economics, Moscow, Russia. E-mail: shvidko72@rambler.ru

(iD http://orcid.org/0000-0002-8653-6396

\section{Iuliia V. Gluzman}

Doctor of Education, Associate Professor, Department of Social and Pedagogical Technologies and Pedagogy of Deviant Behavior , V.I. Vernadsky Crimean Federal University (CUH), Republic of Crimea, Russia. E-mail: yuliya.boginskaya@ya.ru

iD http://orcid.org/0000-0002-6473-7840

\section{Olga I. Shkuropy}

Senior Lecturer of the Department of humanitarian disciplines, Armavir Institute of Mechanics and Technology (branch) of Kuban State Technological University AIMT (branch) of KubSTU. E-mail: olgaskr17@yandex.ru

(iD http://orcid.org/0000-0003-4331-968X

\section{Valentina I. Odintsova}

Ph.D. in in Biological science, a leading researcher, associate Professor, Department of "Theory and Practice of Physical Culture and Sports", Don State Technical University, Rostovon-Don, Russia. E-mail: odintsova1749@ mail.ru

(iD http://orcid.org/0000-0002-5377-3504 